\title{
AMPHICTYON, SON OF HELLEN? A MISUNDERSTOOD MYTHOLOGICAL REFERENCE IN DION. HAL. ANT. ROM. 4.25.3*
}

Virtually all the major scholarly reference works, as well as many more popular sources, provide two alternative versions of the ancestry of Amphictyon, the mythical founder of the Delphic-Pylaic amphictyony, as either the son or the grandson of Deucalion, that is, by implication, either the brother or the son of Hellen. ${ }^{1}$ Yet, a review of all relevant sources shows that they unanimously and exclusively refer to Amphictyon as the son of Deucalion. ${ }^{2}$

${ }^{*}$ Many thanks are due to my friends and colleagues Professor Stephen Halliwell and Dr Myles Lavan as well as the anonymous reader for their helpful comments and suggestions.

${ }^{1}$ Roscher, Lex. 1.305 (H.W. Stoll); Kl. Pauly 1.311 (H. von Geisau); BNP 1.611 (F. Graf); R.L. Fowler, Early Greek Mythography 2 (Oxford, 2013), 142. Cf. further, J. Lempriere, Lorenzo L. Da Ponte and J.D. Ogilby, Bibliotheca Classica, (rev. edn. New York, 1839) s.v. Amphictyon, and the works cited in n. 3. Notable exceptions are P. Grimal, The Penguin Dictionary of Classical Mythology (engl. trans. London, 1986), and $R E 1.1904$ (Wagner), s.v. Amphictyon, which give only the first (correct) alternative, but do not mention or comment on Ant. Rom. 4.25. There is no entry on Amphictyon in either $O C D^{4}$ or $L I M C$.

${ }^{2}$ Roscher (n. 1) cites the most important sources: Theopomp. in Harp. Lexicon in decem oratores Atticos, ed. Dindorf (Oxford, 1853; repr. Groningen, 1969), 28 s.v.

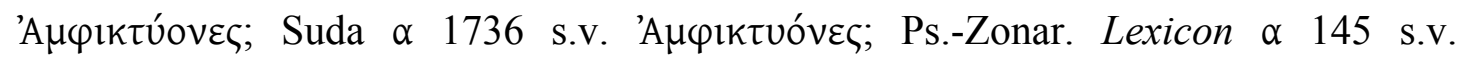
'A 
The only apparent exception, and, in fact, the only passage on which Amphictyon's alleged descent from Hellen relies, is Dion. Hal. Ant. Rom. 4.25.3, where Dionysius

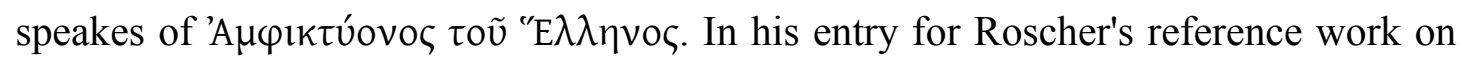
ancient mythology, Stoll took this to mean 'Amphictyon, son of Hellen', and his view was adopted in the works of numerous scholars who followed, or depended on, him (n. 1). Before Stoll, W. Smith read the passage in the same way in his entry on ‘Amphictyon' (Dictionary of Greek and Roman Mythology. London, 1844) from where it appears to have found its way into more popular reference works, including Wikipedia. ${ }^{3}$ In this note I will demonstrate that this translation is wrong and, therefore, the reference to 'Amphictyon, son of Hellen' in modern scholarship spurious.

search further produces Schol. Homer Od. 10.2; Steph. Byz. $\beta 116$ Billerbeck s.v.

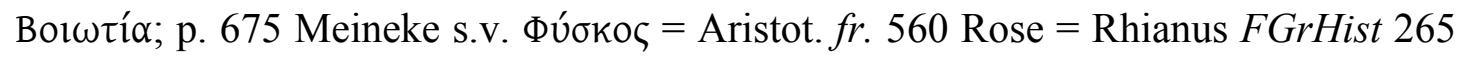
F 57; Ps.-Scymn. Periegesis ad Nicomedem Regem 588-9, in GGM 1.219; Ael. Herodianus, De prosodia catholica, in Gramm. Gr., ed. Lentz, 3.1, 184; Syncell. Ecl. Chron., ed. Mosshammer (Leipzig, 1984), 184; Phot. Lexicon a 1340 s.v.

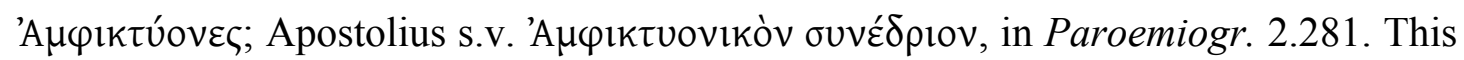
list is exhaustive. Many of these sources depend on each other, but their relationship is beyond the scope of this note.

${ }^{3}$ http://en.wikipedia.org/wiki/Amphictyon, accessed 31/1/2015. Before Smith this reading of the passage is found in, e.g., T. Leland, The History of the Life and Reign of Philip 1 (London, 1758), xxxviii, and H. Fynes Clinton, Fasti Hellenici 1 (Oxford, 1834), 69, as well as the major Latin, French, English and German translations of the Antiquities, going as far back as the sixteenth century (see next n.). 
The main reason why the expression has so often been misunderstood, I surmise, is that scholars have failed to pay sufficient attention to the context. Taken in isolation,

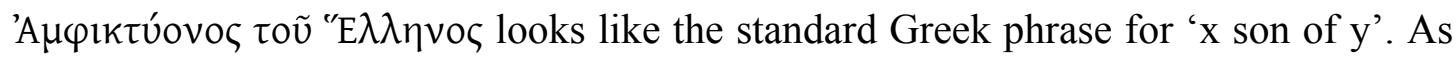
E. Cary phrased it: "The Greek words can mean either "the son of Hellen" or "the Greek"; but the latter does not seem to be a very natural way of describing him' (italics mine). ${ }^{4}$ Cary's note offers us a rare 'glimpse' into the mind of an expert reader of Dionysius' Antiquitates and, hence, an opportunity to formulate a reasonable hypothesis as to why so many scholars (including Cary himself) rejected, or failed to consider in the first place, the less common, but equally possible (and, in this case, correct) translation 'Amphictyon the Greek': consciously or unconsciously, they simply chose the seemingly 'natural' translation of the phrase. ${ }^{5}$

But Cary's note is also exceptional in that he - unlike the majority of scholars who dealt with this passage - at least regarded the problem worth commenting on, and he deserves credit for that. Cary, however, was not the first to notice the ambiguity of the

${ }^{4}$ The Roman Antiquities of Dionysius of Halicarnassus, 2, Loeb Classical Library (Cambridge, Mass. and London, 1939), 352 n. 1; the expression is mistranslated already in Sylburg's (Dionysii Halicarnassei scripta quae extant omnia et historica et rhetorica, Frankfurt, 1586, 229), Emilio Porto's (Dionysii Alexandri F. Halicarn. Antiquitatum Rom. Libri XI. Geneva, 1588, 121) and Reiske's (Dionysii Halicarnassensis operum volumen secundum, Antiquitatum Romanarum libros $I V, V$ et VI tenens, Leipzig, 1774) Latin, G. J. Schaller's (Stuttgart: Metzler 1827) German as well as various French translations of the Antiquities (see nn. 7, 8).

${ }^{5}$ That the entire phrase is in the genitive is probably partly responsible for the problem; see n. 10 below. 
phrase. In fact, further inquiries into the history of translations of the Antiquitates uncover a remarkable backstory to Cary's note which is worth retracing briefly. This will not only offer us insight into a fascinating chapter of the history of scholarship on Dionysius' Antiquitates; it will also be a useful first step of my own examination of the correct meaning of the phrase.

Cary's note, it turns out, was only the last stage of a mini-dispute, as it were, about the correct meaning of Dionysius' phrase carried out in the notes on this passage by previous translators: Cary's note was prompted by a note in Spelman's 1758 translation, ${ }^{6}$ on which Cary's translation is based, while Spelman's own note responded to a note in a French translation of the Antiquities published in 1723 under the name of 'M.***', now identified with François Bellanger.' Noticing that Dionysius was at variance with all other sources in calling Amphictyon the son of Hellen, 'M.***' suggested that the correct translation of the phrase might be 'Amphictyon the Greek'. Spelman, in turn, accepted 'M.***'s point but rejected his solution: at the time of Amphictyon, Spelman claimed, the Greeks were called

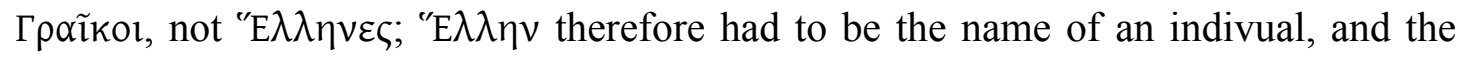
ambiguity of the expression must have been caused by scribal error, namely the omission of $\alpha \delta \varepsilon \lambda \varphi o \tilde{v}$, which Spelman 'restored' and on which his translation 'brother of Hellen' is based.

\footnotetext{
${ }^{6}$ The Roman Antiquities of Dionysius Halicarnassensis, 2 (London, 1758), 197 n. 38.

${ }^{7}$ Les Antiquités Romaines de Denys d'Halicarnasse, 1 (Paris, 1723), 385 n. b. Contrary to what Spelman implies, 'M.***'/ Bellanger does, in fact, translate 'fils d'Hellen' in the main text and considers 'Amphictyon le Grec' only in his note.
} 
'M.***' thus turns out to be the first scholar in the history of translations of Dionysius' Antiquities to have not only noticed the ambiguity of the phrase but also at least pondered the correct translation. ${ }^{8}$ Moreover, his observation that no other source refers to Amphictyon as 'son of Hellen', remains a strong argument for questioning this translation and was by no means refuted by Spelman's objection (see above): 'E $\lambda \lambda \eta v$ is the term Dionysius regularly uses for 'Greek', and his language use alone is relevant to determine the meaning of the phrase; whether (or not) the Greeks at the time of Amphictyon were called Граĩkor, as Spelman claimed, by contrast, is quite immaterial. Neither Spelman's reasoning nor his textual emendation have therefore (and rightly) found any followers. That leaves Cary's attempt to justify his own (and, by implication, Spelman's) translation through recourse to standard ('natural') Greek language use (see above). Yet, a reading of the phrase in context will demonstrate that this argument does not hold up in this case and that ' $\mathrm{M}^{* * *}$ ' was on the right track after all.

At 4.25.3, Dionysius narrates that the Roman king Servius Tullius desired to create an

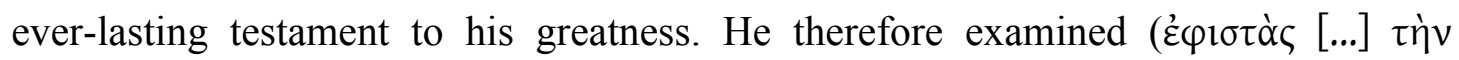
$\delta$ ióvolav) the achievements that had resulted in the permanent glory of some of the

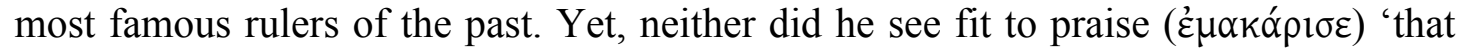
Assyrian woman' ( never names her explicitly), for the walls of Babylon, nor 'the kings of Egypt' (

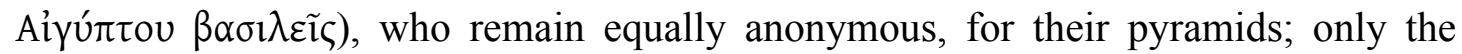

\footnotetext{
${ }^{8}$ Note that shortly before 'M.***', Gabriel François le Jay (Les Antiquitez romaines de Denys d'Halicarnasse, 1. Paris, 1722) had translated 'fils d'Hellen' without comment.
} 


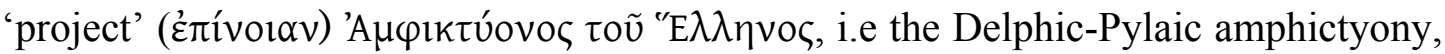

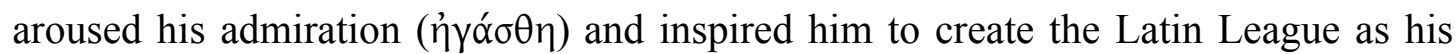
own political (and intellectual) legacy. ${ }^{9}$

After 'Assyrian woman' and 'kings of Egypt', it is not Amphictyon's family tree that Dionysius wants to emphasize, but the fact that it was a Greek whose political legacy lay behind one of the crucial political events of early Roman history, the formation of the Latin League under the leadership of Rome. The correct translation of the expression is therefore 'the Greek Amphictyon'. ${ }^{10}$

This also fits better with the fundamental thesis that informs Dionysius' account of early Rome: Servius Tullius' choice is a further element in Dionysius' interpretation of the Romans as Greeks, both ethnically and culturally. The Roman king chooses the

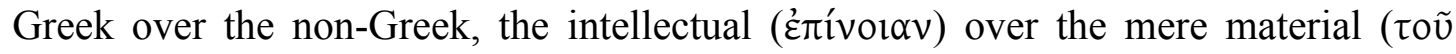

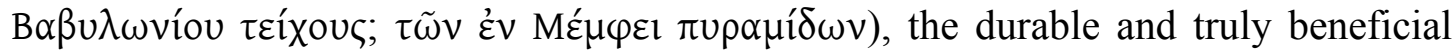

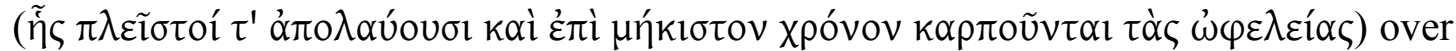

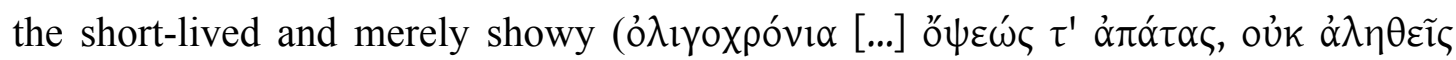

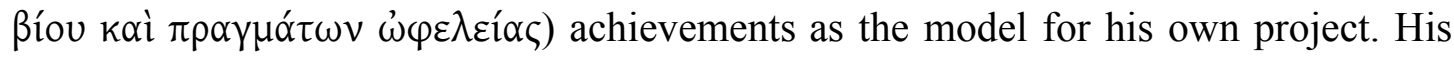

${ }^{9}$ Cf. C. Schultze, 'Negotiating the plupast. Dionysius of Halicarnassus and Roman Self-Definition', in J. Grethlein and C.B. Krebs (edd.), Time and Narrative in Ancient Historiography. The 'Plupast' from Herodotus to Appian (Cambridge, 2012), 113-38, at 129-30. Schultze speaks of 'the Greek hero Amphictyon' (130) but without discussion.

${ }^{10}$ The ambiguity of the expression is partly due to the genitive. If Dionysius had construed the sentence with Amphictyon as the subject, he would have written

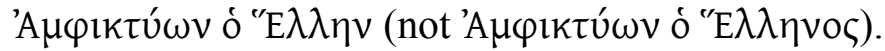


choice thus makes a crucial contribution to establishing the Romans' 'Greek way of life' (ßíov "E $\lambda \lambda \eta v \alpha, 1.90 .1)$ which, according to Dionysius, was ultimately responsible for the unprecedented expansion and duration of their rule. ${ }^{11}$

$\begin{array}{ll}\text { University of St Andrews } & \text { N. WIATER }\end{array}$

WORD COUNT: 1,821

11 On this well-known aspect of the Antiquitates see, most recently, E. Gabba, Dionysius and The History of Archaic Rome (Berkeley, 1991); A. Delcourt, Lecture des Antiquités romaines de Denys d'Halicarnasse. Un historien entre deux mondes (Brussels, 2005); N. Wiater, The Ideology of Classicism. Language, History, and Identity in Dionysius of Halicarnassus (Berlin, 2011), 120-225 (all with further literature). Cf. A. Spawforth, Greece and the Augustan Cultural Revolution (Oxford, 2012), 161. 